Prepared in cooperation with Northern Arizona University

\title{
Colorado River Campsite Monitoring, Grand Canyon National Park, Arizona, 1998-2012
}

Open-File Report 2014-1161 



\section{Colorado River Campsite Monitoring, Grand Canyon National Park, Arizona, 1998-2012}

By Matt Kaplinski, Joe Hazel, Rod Parnell, Daniel R. Hadley, and Paul Grams

Prepared in cooperation with Northern Arizona University

Open-File Report 2014-1161

U.S. Department of the Interior

U.S. Geological Survey 


\section{U.S. Department of the Interior \\ SALLY JEWELL, Secretary}

\section{U.S. Geological Survey \\ Suzette M. Kimball, Acting Director}

U.S. Geological Survey, Reston, Virginia: 2014

For more information on the USGS-the Federal source for science about the Earth,

its natural and living resources, natural hazards, and the environment-visit

http://www.usgs.gov or call 1-888-ASK-USGS

For an overview of USGS information products, including maps, imagery, and publications, visit $h$ ttp://www.usgs.gov/pubprod

To order this and other USGS information products, visit $h$ ttp://store.usgs.gov

Suggested citation:

Kaplinski, Matt, Hazel, Joe, Parnell, Rod, Hadley, D.R., and Grams, Paul, 2014, Colorado River campsite monitoring, Grand Canyon National Park, Arizona, 1998-2012: U.S. Geological Survey Open-File Report 2014-1161, 24 p. plus appendix, http://dx.doi.org/10.3133/ofr20141161.

ISSN 2331-1258 (online)

Any use of trade, firm, or product names is for descriptive purposes only and does not imply endorsement by the U.S. Government.

Although this information product, for the most part, is in the public domain, it also may contain copyrighted materials as noted in the text. Permission to reproduce copyrighted items must be secured from the copyright owner. 


\section{Contents}

Abstract

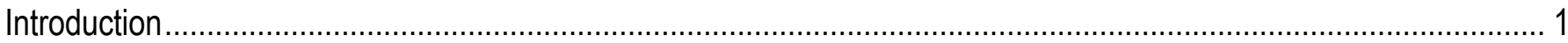

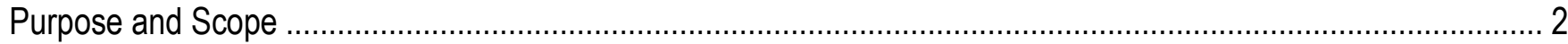

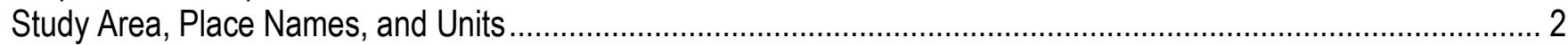

Glen Canyon Dam Flows Releases during Study Period …….................................................................... 4

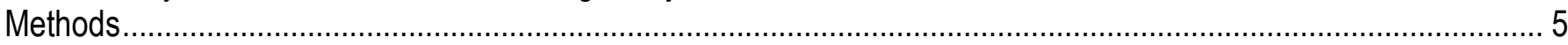

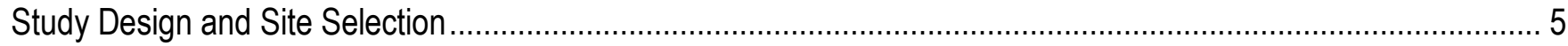

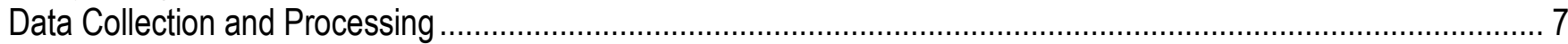

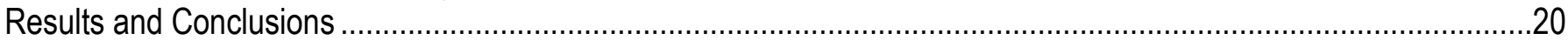

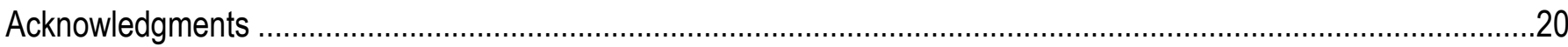

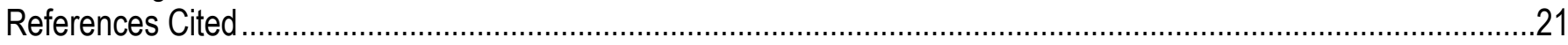

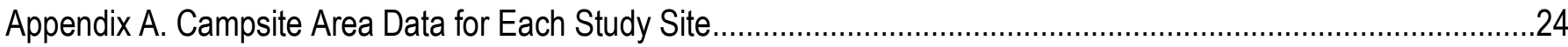

\section{Figures}

Figure 1. Map showing campsite area study site locations along the Colorado River, Grand Canyon

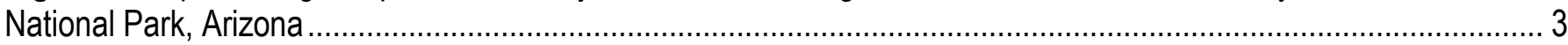

Figure 2. Hydrograph showing the Colorado River at Lees Ferry (09380000), Arizona, 1998-2013 ......................... 4

Figure 3. Map showing repeat surveys of Nautiloid camp (RM 35.0) conducted on October 12, 1998 at 16:00 and 17:00 by independent survey crews ........................................................................................... 9

Figure 4. Time series plots showing mean campsite area for all sites along the Colorado River, Grand Canyon

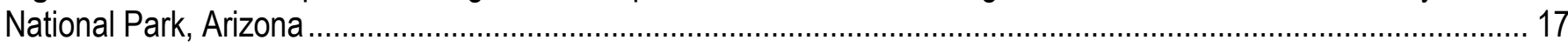

Figure 5. Time series plots showing mean campsite area for sites in Marble and Grand Canyons along the Colorado River, Grand Canyon National Park, Arizona

Figure 6. Time series plots showing mean campsite area for sites in critical and non-critical recreational segments along the Colorado River, Grand Canyon National Park, Arizona

\section{Tables}

Table 1. Campsite monitoring study sites, along the Colorado River, Grand Canyon National Park, Arizona

Table 2. Campsite survey trip data collected along the Colorado River, Grand Canyon National Park, Arizona, 1998-2012.

Table 3. Mean campsite area for all sites in low, high, and total stage elevation zones along the Colorado River, Grand Canyon National Park, Arizona, 1998-2012

Table 4. Mean campsite area for sites in low, high, and total stage elevation zones in Marble Canyon along the Colorado River, Arizona, 1998-2012.

Table 5. Mean campsite area for sites in low, high, and total stage elevation zones in Grand Canyon along the Colorado River, Grand Canyon National Park, Arizona, 1998-2012

Table 6. Mean campsite area for sites in critical reaches in low, high, and total stage elevation zones along the Colorado River, Grand Canyon National Park, Arizona, 1998-2012

Table 7. Mean campsite area for sites in non-critical reaches in low, high, and total stage elevation zones along the Colorado River, Grand Canyon National Park, Arizona, 1998-2012

Table 8. Results of linear regression of mean campsite-area time series presented in tables 2 through 6 , Grand Canyon National Park, Arizona, 1998-2012 


\section{Conversion Factors}

Inch/Pound to SI

\begin{tabular}{lcl}
\hline \multicolumn{1}{c}{ Multiply } & \multicolumn{1}{c}{ By } & \multicolumn{1}{c}{ To obtain } \\
\hline foot $(\mathrm{ft})$ & Length & \\
mile $(\mathrm{mi})$ & 0.3048 & meter $(\mathrm{m})$ \\
\hline & 1.609 & kilometer $(\mathrm{km})$ \\
\hline square foot $\left(\mathrm{ft}^{2}\right)$ & Area & \\
\hline & 0.09290 & square meter $\left(\mathrm{m}^{2}\right)$ \\
\hline cubic foot $\left(\mathrm{ft}^{3}\right)$ & Volume & \\
\hline & 0.02832 & cubic meter $\left(\mathrm{m}^{3}\right)$ \\
\hline cubic foot per second $\left(\mathrm{ft}^{3} / \mathrm{s}\right)$ & Flow rate & \\
\hline
\end{tabular}

SI to Inch/Pound

\begin{tabular}{lll}
\hline \multicolumn{1}{c}{ Multiply } & \multicolumn{1}{c}{ By } & \multicolumn{1}{c}{ To obtain } \\
\hline meter $(\mathrm{m})$ & Length & \\
kilometer $(\mathrm{km})$ & 3.281 & foot $(\mathrm{ft})$ \\
& 0.6214 & mile $(\mathrm{mi})$ \\
\hline cubic meter $\left(\mathrm{m}^{3}\right)$ & Volume & \\
\hline & 35.31 & cubic foot $\left(\mathrm{ft}^{3}\right)$ \\
\hline cubic meter per second $\left(\mathrm{m}^{3} / \mathrm{s}\right)$ & Flow rate & \\
\hline
\end{tabular}

Horizontal coordinate information is referenced to the North American Datum of 1983 (NAD 83).

Elevation, as used in this report, refers to distance above the vertical datum. 


\title{
Colorado River Campsite Monitoring, Grand Canyon National Park, Arizona, 1998-2012
}

\author{
By Matt Kaplinski, Joe Hazel, Rod Parnell, Daniel R. Hadley, and Paul Grams
}

\begin{abstract}
River rafting trips and hikers use sandbars along the Colorado River in Marble and Grand Canyons as campsites. The U.S. Geological Survey evaluated the effects of Glen Canyon Dam operations on campsite areas on sandbars along the Colorado River in Grand Canyon National Park. Campsite area was measured annually from 1998 to 2012 at 37 study sites between Lees Ferry and Diamond Creek, Arizona. The primary purpose of this report is to present the methods and results of the project.

Campsite area surveys were conducted using total station survey methods to outline the perimeter of camping area at each study site. Campsite area is defined as any region of smooth substrate (most commonly sand) with no more than an 8 degree slope and little or no vegetation. We used this definition, but relaxed the slope criteria to include steeper areas near boat mooring locations where campers typically establish their kitchens.

The results show that campsite area decreased over the course of the study period, but at a rate that varied by elevation zone and by survey period. Time-series plots show that from 1998 to 2012, high stage-elevation (greater than the $25,000 \mathrm{ft}^{3} / \mathrm{s}$ stage-elevation) campsite area decreased significantly, although there was no significant trend in low stage-elevation $\left(15,000-20,000 \mathrm{ft}^{3} / \mathrm{s}\right)$ campsite area. High stage-elevation campsite area increased after the 2004 and 2008 high flows, but decreased in the intervals between high flows. Although no overall trend was detected for low stage-elevation campsite areas, they did increase after high-volume dam releases equal to or greater than about $20,000 \mathrm{ft}^{3} / \mathrm{s}$. We conclude that dam operations have not met the management objectives of the Glen Canyon Adaptive Management program to increase the size of camping beaches in critical and non-critical reaches of the Colorado River between Glen Canyon Dam and Lake Mead.
\end{abstract}

\section{Introduction}

Approximately 25,000 river runners and hikers visit and camp along the corridor of the Colorado River in Grand Canyon National Park every year (National Park Service, 2006). Because the banks are dominated by bedrock cliffs, rocky talus, and boulder-covered debris fans (Howard and Dolan, 1981), suitable locations for camping are limited in many places. Most campsites are located on sandbars because these alluvial deposits are relatively flat and easily accessible from the river. Sandbars occur intermittently along the shorelines, and campsites are abundant wherever sandbars are abundant. As the number of visitors to the Colorado River corridor in Grand Canyon National Park (GCNP) has increased since the mid-1960s, the distribution and quality of campsites have become an increasingly important concern to river managers (U.S. Department of Interior, 1995; National Research Council, 1999; Stewart and others, 2000; Bureau of Reclamation, 2001; National Park Service, 2006). 
Because most campsites are located on sandbars, management of the two resources is intimately linked. Sandbars are dynamic landforms deposited in eddies at times of high streamflow and high suspended-sediment concentration. Sandbars may be eroded by streamflows that have low suspendedsediment concentration (Hazel and others, 1999), and sandbars also may be eroded by hillslope runoff (Melis and others, 2004), wind deflation (Draut and Rubin, 2007), and human activity (Phillips and others, 1986).

The completion of Glen Canyon Dam (GCD) in 1963 caused a 95 percent reduction in the delivery of fine sediment to the Colorado River in Marble and Grand Canyons (Topping and others, 2000). High suspended-sediment streamflows are now rare, and sandbar erosion has generally outpaced deposition (Rubin and others, 2002; Schmidt and others, 2004; Wright and others, 2005). Flow regulation also reduced the magnitude and frequency of floods that reorganized the configuration of sandbars and scoured riparian plants from the banks of the river. The number and size of plants increased after 1965, colonizing formerly open sandbars that had been used as campsites (Turner and Karpiscak, 1980; Kearsley and Ayers, 1996; Webb and others, 2002). The rate of increase in riparian vegetation along the river margins has increased greatly since the early 1990s (Sankey, written commun., 2013). Because of the combined impacts of sandbar erosion and invasion by riparian plants, the number and size of campsites has decreased dramatically in the post-dam river (Kearsley and others, 1994; Kaplinski and others, 2005; Kaplinski and others, 2010).

\section{Purpose and Scope}

Improving the condition of campsites along the Colorado River in Grand Canyon National Park is a priority management objective of the Glen Canyon Dam Adaptive Management Program (GCDAMP). The GCDAMP Strategic Plan management objective 9.3 calls for an increase in the "... size, quality, and distribution of camping beaches in critical and non-critical reaches..." of the Colorado River between Glen Canyon Dam and Lake Mead (Bureau of Reclamation, 2001). To address this objective, the U.S. Geological Survey, in cooperation with Northern Arizona University, conducted an integrated program of sandbar and campsite monitoring that was aimed at understanding the effects of Glen Canyon Dam operations on sandbars and campsites. This report describes the methods used to monitor 37 sandbar campsites and the changes that occurred to those campsites between 1998 and 2012. A companion report describes the monitoring program for the sandbar component of the study.

\section{Study Area, Place Names, and Units}

The study area is the 225-mi (362 km) segment of the Colorado River between Lees Ferry and Diamond Creek, Arizona (fig. 1). The study area is subdivided into Marble Canyon, which extends between Lees Ferry and the confluence with the Little Colorado River, and Grand Canyon, which extends from the Little Colorado River to Diamond Creek. Locations along the river corridor are referenced by convention as river mile (RM), which is distance, in miles, along the channel centerline downstream of Lees Ferry (U.S. Geological Survey, 2013). Lees Ferry (RM 0) is located 15.5 mi (25 $\mathrm{km})$ downstream from GCD, and $1 \mathrm{mi}(1.6 \mathrm{~km})$ upstream from the mouth of the Paria River and the northeastern boundary of Grand Canyon National Park (fig. 1). The Little Colorado River confluence is at RM 61.5, and Diamond Creek enters the Colorado River at RM 225. 


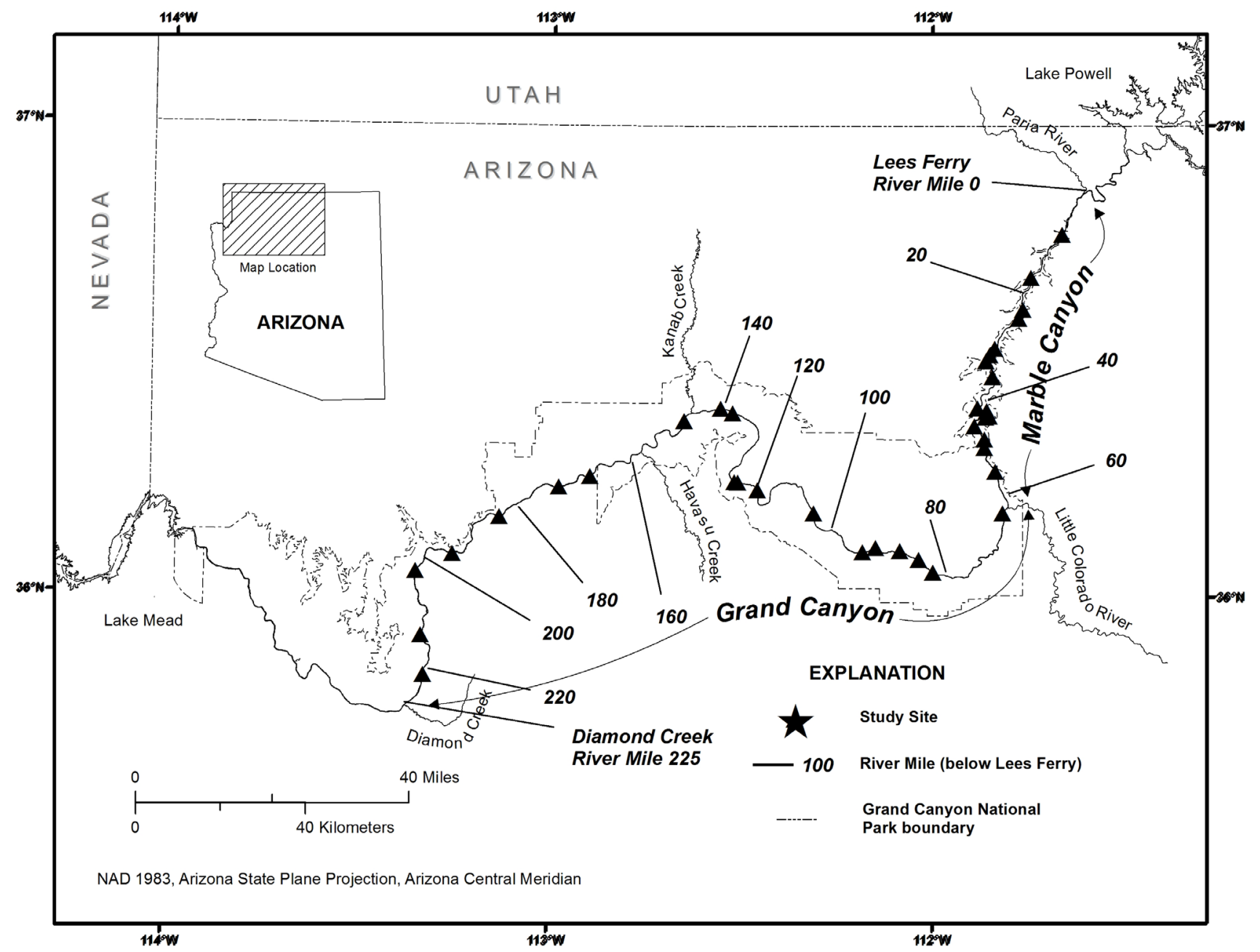

Figure 1. Map showing campsite area study site locations along the Colorado River, Grand Canyon National Park, Arizona.

Study sites are identified by RM and place name after Stevens (1990) and Belknap (2001). The left and right sides of the Colorado River are determined as facing downstream. Different parts of the Colorado River corridor in Marble and Grand Canyons have been classified as critical and non-critical recreational segments, as defined by Kearsley and Warren (1993). Critical segments are stretches of the river in which the number of available campsites is limited because of geomorphic setting, high demand for nearby attraction sites, or other logistical factors. Non-critical segments are stretches in which campsites are plentiful, resulting in little competition for most sites. Each campsite described in this report is located in a critical or a noncritical recreational segment. The International System of Units is used for all measures except for river mile, as noted above, and discharge, which is reported in cubic feet per second $\left(\mathrm{ft}^{3} / \mathrm{s}\right)$. 


\section{Glen Canyon Dam Flows Releases during Study Period}

Flows during the study period (fig. 2) followed the Modified Low Fluctuation Flow (MLFF) preferred alternative of the 1996 Record of Decision on the Glen Canyon Dam Environmental Impact statement (U.S. Department of Interior, 1996). The MLFF restricted minimum and maximum flows to 5,000 and $25,000 \mathrm{ft}^{3} / \mathrm{s}$, respectively, and included low-, medium-, and high-volume months, with low flows during the late spring and late autumn, moderate flows in May and September, and high flows during mid-summer and mid-winter. The daily fluctuation or range in flow was limited to $5,000 \mathrm{ft}^{3} / \mathrm{s}$ during low-volume months, $5,000 \mathrm{ft}^{3} / \mathrm{s}$ during medium-volume months, and 8,000 $\mathrm{ft}^{3} / \mathrm{s}$ during highvolume months. In this report, flow releases regulated by the MLFF protocols are referred to as "normal dam operations."

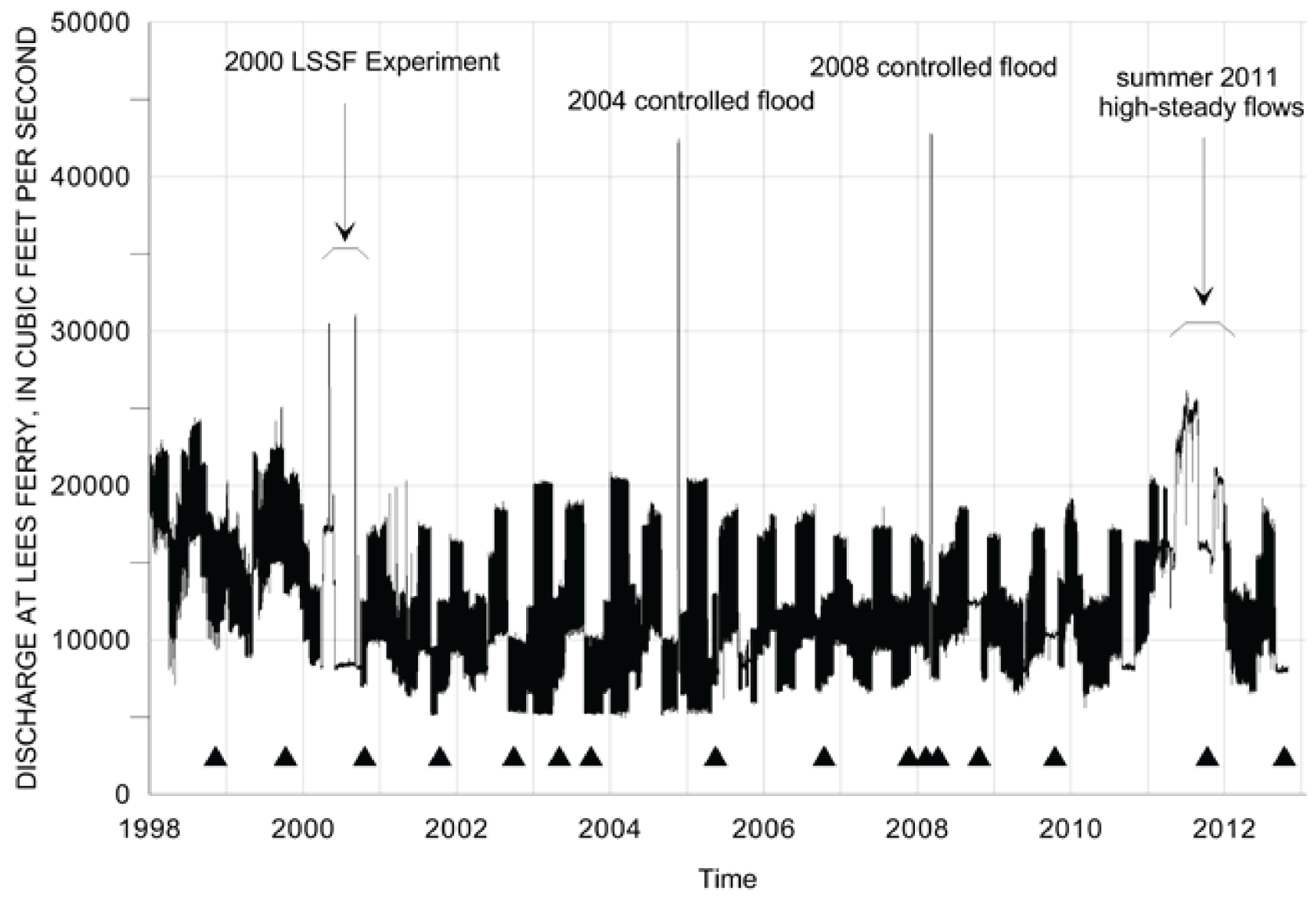

Figure 2. Hydrograph showing the Colorado River at Lees Ferry (09380000), Arizona, 1998-2013. Survey trip dates are shown as triangles. Note the daily and seasonal fluctuations in discharge volume, the May and September 30,000 ft3/s powerplant capacity flows during the 2000 Low Steady Summer Flow (LSSF) experiment, the November 2004 High Flow experiment, March 2008 High Flow experiment, and sustained high volume flows during the summer of 2011. 
During the study period, several flows were released that deviated from the MLFF operating guidelines. These flows were either experiments (such as controlled floods), or the result of equalization flows between Lake Powell and Lake Mead. Five high-flow releases occurred during the study period and are of particular interest, as they resulted in elevated main stem discharge that inundated sandbars and affected campsite areas. We refer to these flow events as "controlled floods." The first two controlled floods occurred in May and September 2000 as part of a flow experiment termed the Low Summer Steady Flow Experiment (LSSF). The LSSF consisted of a 4-day power-plant capacity controlled flood of 30,000 $\mathrm{ft}^{3} / \mathrm{s}$ that was released in May 2000, followed by 3 months of constant 8,000 $\mathrm{ft}^{3} / \mathrm{s}$ discharge, and then another 4-day power plant capacity controlled flood in September 2000. Two controlled floods greater than powerplant capacity were released in November 2004 and March 2008. Both of these controlled floods consisted of a 60-hour release of $42,000 \mathrm{ft}^{3} / \mathrm{s}$. In 2003, 2004, and 2005, high-fluctuating flow experiments were conducted from January through March of each year. Flows during these months consisted of diurnal fluctuations from 5,000 to $20,000 \mathrm{ft}^{3} / \mathrm{s}$. A non-experimental flow that affected campsite area occurred from June 1 to August 31,2011. We refer to these flow releases as the "summer 2011 high-steady flows," during which equalization flows governed by the interim operating criteria averaged approximately $25,000 \mathrm{ft}^{3} / \mathrm{s}$, with no daily fluctuation (U.S. Department of Interior, 2007).

\section{Methods}

\section{Study Design and Site Selection}

The objective of this study was to monitor changes in campsite areas associated with changing sandbar condition and to relate these changes to operations of Glen Canyon Dam. The study was designed as a companion component of a sandbar monitoring project in which the area and volume of sandbars at selected monitoring sites is measured at least annually by topographic survey (Beus and others, 1992; Kaplinski and others, 1995; Hazel and others, 1999; Hazel and others, 2010). Sandbars monitored for change in campsite area are a subset of the sites measured for topographic change, because not all sandbars are used as campsites. The original criteria for selection of the sandbar monitoring sites were (1) distribution throughout the river corridor, (2) distribution of geomorphic settings, (3) availability of historical data, (4) variation in recreation use intensity, and (5) variation in vegetation cover (Beus and others, 1992). Some of the current sandbar and campsite area monitoring sites were established by other researchers in the 1970s or 1980s (Howard and Dolan, 1981; Beus and others, 1985; Schmidt and Graf, 1990). A total of 37 study sites are monitored for changes in campsite area and provide the basis for this report (table 1). Thirty two sites were initially selected in 1998, and an additional five sites were added in 2002. These campsites comprise approximately 10 percent of all the sandbars identified as campsites by Grand Canyon National Park (http://www.nps.gov/grca/parkmgmt/upload/2011CampsiteList.pdf).

The locations, informal camp names, and reach designation of the 37 sites are shown in table 1. Sixteen of the study sites are in Marble Canyon, and 21 are in Grand Canyon (fig. 1). Sixteen sites are located in critical reaches, and 21 are in non-critical reaches. No campsites upstream of Lees Ferry in Glen Canyon (RM -15 to 0) or downstream of Diamond Creek (RM 225) were evaluated. 
Table 1. Campsite monitoring study sites, along the Colorado River, Grand Canyon National Park, Arizona.

\begin{tabular}{|c|c|c|c|}
\hline Mile $^{1}$ & Side & Name & Reach $^{2}$ \\
\hline 8.1 & $\mathrm{~L}$ & Jackass & $\mathrm{NC}$ \\
\hline 16.6 & $\mathrm{~L}$ & $\mathrm{Hot} \mathrm{Na} \mathrm{Na}$ & $\mathrm{C}$ \\
\hline 22.1 & $\mathrm{R}$ & 22 Mile & $\mathrm{C}$ \\
\hline 23.5 & $\mathrm{~L}$ & Lone Cedar & $\mathrm{C}$ \\
\hline 29.5 & $\mathrm{~L}$ & Silver Grotto & $\mathrm{C}$ \\
\hline 30.7 & $\mathrm{R}$ & Sand Pile & $\mathrm{C}$ \\
\hline 31.9 & $\mathrm{R}$ & South Canyon & $\mathrm{C}$ \\
\hline 35.0 & $\mathrm{~L}$ & Nautiloid & $\mathrm{C}$ \\
\hline 41.2 & $\mathrm{R}$ & Buck Farm & $\mathrm{NC}$ \\
\hline 43.4 & $\mathrm{~L}$ & Anasazi Bridge & $\mathrm{NC}$ \\
\hline 44.5 & $\mathrm{~L}$ & Eminence & $\mathrm{NC}$ \\
\hline 45.0 & $\mathrm{~L}$ & Willy Taylor & $\mathrm{NC}$ \\
\hline 47.6 & $\mathrm{R}$ & Lower Saddle & $\mathrm{NC}$ \\
\hline 50.1 & $\mathrm{R}$ & Dino & $\mathrm{NC}$ \\
\hline 51.5 & $\mathrm{~L}$ & 51 Mile & $\mathrm{NC}$ \\
\hline 55.9 & $\mathrm{R}$ & Kwagunt Marsh & $\mathrm{NC}$ \\
\hline 62.9 & $\mathrm{R}$ & Crash & $\mathrm{NC}$ \\
\hline 81.7 & $\mathrm{~L}$ & Grapevine & $\mathrm{C}$ \\
\hline 84.6 & $\mathrm{R}$ & Clear Creek & $\mathrm{C}$ \\
\hline 87.7 & $\mathrm{~L}$ & Cremation & $\mathrm{C}$ \\
\hline 91.7 & $\mathrm{R}$ & 91 mile - above Trinity & $\mathrm{C}$ \\
\hline 93.8 & $\mathrm{~L}$ & Granite & $\mathrm{C}$ \\
\hline 104.4 & $\mathrm{R}$ & 104 Mile & $\mathrm{C}$ \\
\hline 119.4 & $\mathrm{R}$ & 119 Mile & $\mathrm{NC}$ \\
\hline 122.8 & $\mathrm{R}$ & 122 Mile & $\mathrm{NC}$ \\
\hline 123.2 & $\mathrm{~L}$ & Forster & $\mathrm{NC}$ \\
\hline 137.7 & $\mathrm{~L}$ & Football Field & $\mathrm{C}$ \\
\hline 139.6 & $\mathrm{R}$ & Fishtail & $\mathrm{C}$ \\
\hline 145.9 & $\mathrm{~L}$ & 145 Mile & $\mathrm{C}$ \\
\hline 167.1 & $\mathrm{~L}$ & Lower National & $\mathrm{NC}$ \\
\hline 172.2 & $\mathrm{~L}$ & 172 Mile & $\mathrm{NC}$ \\
\hline 183.3 & $\mathrm{R}$ & 183Left & $\mathrm{NC}$ \\
\hline 183.3 & $\mathrm{~L}$ & 183 Right & $\mathrm{NC}$ \\
\hline 194.6 & $\mathrm{~L}$ & 194 Mile & $\mathrm{NC}$ \\
\hline 202.3 & $\mathrm{R}$ & 202 Mile & $\mathrm{NC}$ \\
\hline 213.3 & $\mathrm{~L}$ & Pumpkin Springs & $\mathrm{NC}$ \\
\hline 220.1 & $\mathrm{R}$ & Middle 220 Mile & $\mathrm{NC}$ \\
\hline
\end{tabular}

${ }^{1}$ Based on the river mile centerline (U.S. Geological Survey, 2013) downstream from Lees Ferry (river mile 0)

${ }^{2} \mathrm{C}=$ Critical Reach, $\mathrm{NC}=$ Non-Critical Reach, as defined by Kearsley and Warren (1993). 


\section{Data Collection and Processing}

There are no administrative definitions of what constitutes a campsite, and the National Park Service (NPS) has few regulations that dictate campsite use. Aside from a few areas that are closed to camping, river runners camp anywhere they choose. Visitors are, however, discouraged from camping in previously undisturbed areas and clearing vegetation to establish new camping areas is not allowed. Most river runners camp at sites that are repeatedly used throughout the river running season; some sites are used nearly every night during the summer.

Because the purpose of this project is to track changes in the areas available for camping at regularly used sites, we adopted a definition of "campsite area" similar to that used by the NPS in previous studies (Kearsley and Warren, 1993). Campsite area is defined as any area of smooth substrate (most commonly sand) with no more than an 8 degree slope and little or no vegetation. We used this definition, but relaxed the slope criteria to include steeper areas near boat mooring locations where campers typically establish their kitchens. Following this definition, a single campsite consists of any number of smaller areas that meet the above criteria.

Campsite area was surveyed on 16 trips between 1998 and 2012 (fig. 2, table 2). Campsite surveys were conducted using standard total-station survey techniques. Hazel and others (2008) reported that individual points collected with total stations have horizontal accuracies that range from \pm 0.05 to $0.25 \mathrm{~m}$ and vertical accuracies that range from \pm 0.05 to $0.09 \mathrm{~m}$, depending on the number of rod extensions used. Approximately 90 percent of the points were collected at the standard rod height with no extensions, where the accuracy is closer to the minimum level of $0.05 \mathrm{~m}$, both horizontally and vertically. Each campsite survey was completed by measuring topographic points that outlined the perimeter of areas that meet the campsite area criteria, as well as collecting points to exclude areas containing features within campsite areas such as trees, bushes, and rocks. The perimeter points were then used to define polygons of campsite area (fig. 3). Slope was visually estimated in the field.

We did not include all campsite areas at every study site. Some campsites are large, and areas outside a fixed outer perimeter were not monitored. The areas excluded from monitoring were located far from mooring and kitchen locations and were typically at high elevations (greater than $45,000 \mathrm{ft}^{3} / \mathrm{s}$ ) where current NPS regulations discourage camping (National Park Service, 2006). At other sites, some of the campsite area was obstructed from view by the survey equipment and was not included. At every site, the area for repeat monitoring was consistently defined. Survey crews used orthophotographs of each site with previously surveyed areas plotted to ensure that previously excluded campsite areas were not included in the mapping.

Because delineation of campsite area involves some unavoidable subjectivity, the question arises as to whether or not campsite area mapping, using the methods described above, can be accurately repeated. The repeatability of campsite area mapping was investigated by conducting surveys of the same campsite (Nautiloid camp; RM 35.0; appendix A) on the same day by two separate crews during the 1998 survey trip (fig. 3). Each crew established their own point locations to define the campsite area. The total amount of campsite area measured by the two surveys was 751 and $723 \mathrm{~m}^{2}$, a 3.7 percent difference in campsite area. Topographic and campsite area complexity varies between the study sites; therefore, we conservatively estimate that the methods described here can detect changes in campsite area greater than 10 percent for all sites. Additional repeat surveys will be conducted in the future to better define the range of uncertainty associated with the mapping. 
Table 2. Campsite survey trip data collected along the Colorado River, Grand Canyon National Park, Arizona, 1998-2012.

\begin{tabular}{cccc}
\hline Trip date & Start date & End date & Discharge during surveys \\
\hline October 1998 & $10 / 10 / 1998$ & $10 / 22 / 1998$ & $10,000-18,000 \mathrm{ft}^{3} / \mathrm{s}$ \\
October 1999 & $10 / 3 / 1999$ & $10 / 14 / 1999$ & $13,000-20,000 \mathrm{ft}^{3} / \mathrm{s}$ \\
October 2000 & $10 / 15 / 2000$ & $10 / 27 / 2000$ & $7,000-12,500 \mathrm{ft}^{3} / \mathrm{s}$ \\
October 2001 & $10 / 5 / 2001$ & $10 / 18 / 2001$ & $7,000-12,500 \mathrm{ft}^{3} / \mathrm{s}$ \\
October 2002 & $9 / 20 / 2002$ & $10 / 6 / 2002$ & $5,500-10,000 \mathrm{ft}^{3} / \mathrm{s}$ \\
May 2003 & $4 / 25 / 2003$ & $5 / 12 / 2003$ & $7,000-13,000 \mathrm{ft}^{3} / \mathrm{s}$ \\
October 2003 & $9 / 20 / 2003$ & $10 / 6 / 2003$ & $5,500-10,000 \mathrm{ft}^{3} / \mathrm{s}$ \\
May 2005 & $5 / 7 / 2005$ & $5 / 22 / 2005$ & $7,000-13,000 \mathrm{ft}^{3} / \mathrm{s}$ \\
October 2006 & $10 / 7 / 2006$ & $10 / 22 / 2006$ & $7,000-13,000 \mathrm{ft}^{3} / \mathrm{s}$ \\
October 2007 & $10 / 13 / 2007$ & $10 / 29 / 2007$ & $7,000-13,000 \mathrm{ft}^{3} / \mathrm{s}$ \\
February 2008 & $2 / 2 / 2008$ & $2 / 17 / 2008$ & $8,500-13,500 \mathrm{ft}^{3} / \mathrm{s}$ \\
April 2008 & $3 / 28 / 2008$ & $4 / 12 / 2008$ & $7,500-13,000 \mathrm{ft}^{3} / \mathrm{s}$ \\
October 2008 & $10 / 11 / 2008$ & $10 / 26 / 2008$ & $12,100-12,600 \mathrm{ft}^{3} / \mathrm{s}$ \\
October 2009 & $10 / 10 / 2009$ & $10 / 25 / 2009$ & $10,000-10,700 \mathrm{ft}^{3} / \mathrm{s}$ \\
October 2011 & $10 / 5 / 2011$ & $10 / 20 / 2011$ & $15,000-16,300 \mathrm{ft}^{3} / \mathrm{s}$ \\
October 2012 & $10 / 3 / 2012$ & $10 / 18 / 2012$ & $7,800-8,300 \mathrm{ft}^{3} / \mathrm{s}$ \\
\hline
\end{tabular}

${ }^{1}$ Flow levels from USGS gage (09380000) Colorado River at Lees Ferry, AZ.

The elevation of campsite areas relative to the river elevation is also important when river runners decide where to camp because it is undesirable to carry equipment long distances or far upslope. A campsite is also undesirable if it can be temporarily flooded. To account for fluctuating flows on campsite areas, the campsite surveys were integrated with the topographic surveys so that changes to the campsite area could be analyzed within specific ranges of discharge. Surveys were integrated by constructing Digital Elevation Models (DEM) within the campsite area polygons. DEMs of the site topography were constructed from the survey points using triangular irregular networks (TINs) by Delaunay triangulation (McCullagh, 1998), and campsite area polygons were used to clip the DEM boundary to produce a DEM within the campsite area polygons. The campsite area DEMs were used to tabulate campsite area within six discrete discharge ranges, or zones. These zones were: (1) 10,000 $15,000 \mathrm{ft}^{3} / \mathrm{s}$, (2) $15,000-20,000 \mathrm{ft}^{3} / \mathrm{s}$, (3) $20,000-25,000 \mathrm{ft}^{3} / \mathrm{s}$, (4) $25,000-30,000 \mathrm{ft}^{3} / \mathrm{s}$, (5) $30,000-45,000$ $\mathrm{ft}^{3} / \mathrm{s}$, and (6) greater than $45,000 \mathrm{ft}^{3} / \mathrm{s}$. For each site, these discharge ranges were converted into elevation ranges based on local stage-to-discharge relations computed by Hazel and others (2006). The lowermost stage range $\left(10,000-15,000 \mathrm{ft}^{3} / \mathrm{s}\right)$ could not always be surveyed for all sites because discharges often were greater than $10,000 \mathrm{ft}^{3} / \mathrm{s}$ during the survey trips (table 2). Data for this zone is included only in the tabulation of individual site data (appendix A). 


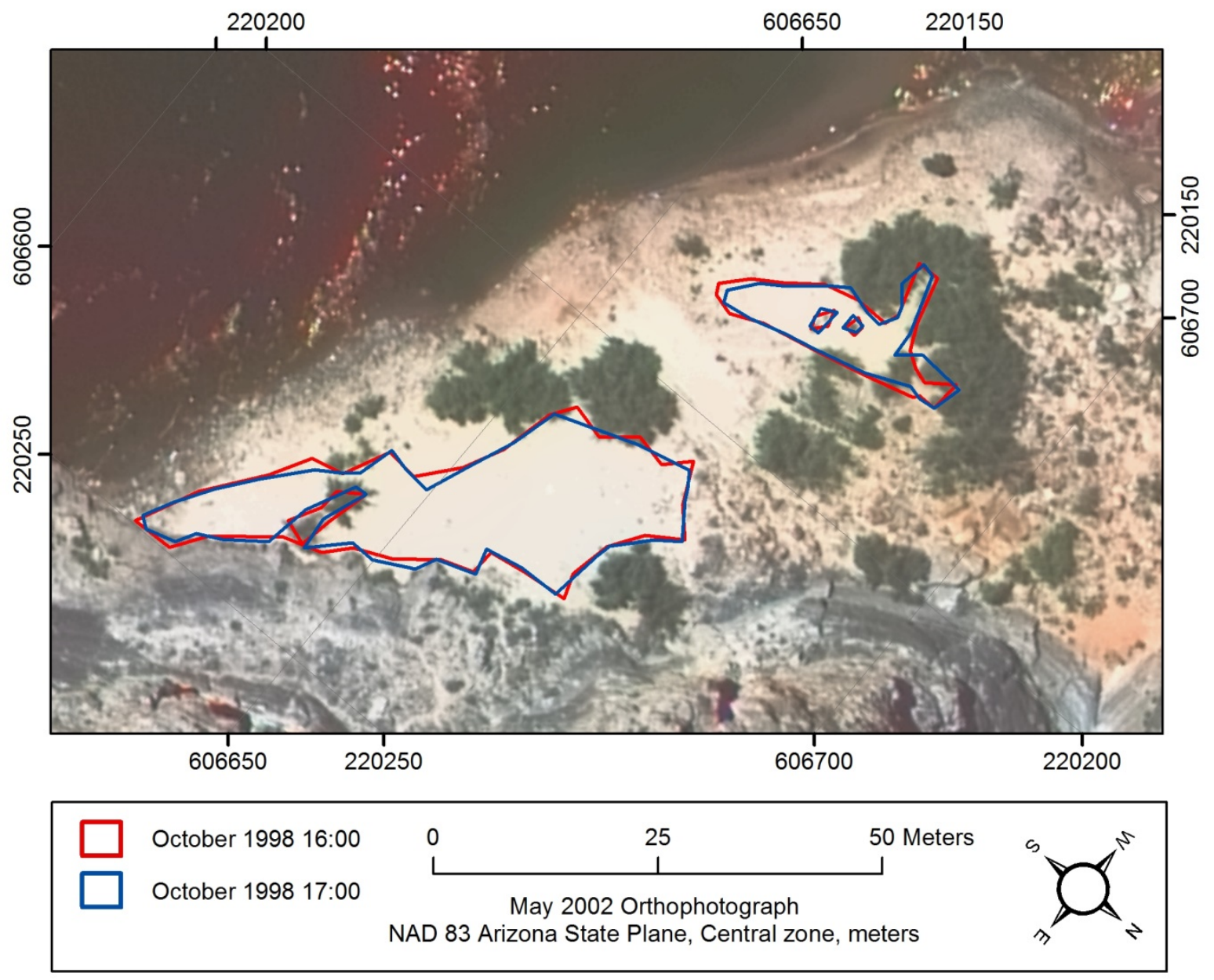

Figure 3. Map showing repeat surveys of Nautiloid camp (RM 35.0) conducted on October 12, 1998 at 16:00 and 17:00 by independent survey crews. The total campsite area measured was $751 \mathrm{~m}^{2}$ (16:00) and $723 \mathrm{~m}^{2}$ (17:00), which equates to a 3.7 percent difference in campsite area between surveys. Flow in main channel was from right to left. Grand Canyon Monitoring and Research Center aerial photographs taken in May 2002 when discharge was approximately $8,000 \mathrm{ft} 3 / \mathrm{s}$. 
Campsite area measurements were summarized by grouping the data into two zones that are of greatest management interest. Normal dam operations generally consist of discharges with peaks rarely exceeding $25,000 \mathrm{ft}^{3} / \mathrm{s}$ (fig. 2). Discharges greater than this occur only during experimental floods conducted to build sandbars (Schmidt and Grams, 2011). We reported "low stage-elevation" campsite area as the sum of all campsite area in the zones between 15,000 and $25,000 \mathrm{ft}^{3} / \mathrm{s}$. These areas are most affected by normal dam operations, are subjected to depositional and erosional processes, and are where riparian vegetation has established only to a minor degree. The "high stage-elevation" campsite area consists of all zones at elevations higher than $25,000 \mathrm{ft}^{3} / \mathrm{s}$. The high stage-elevation zone is situated above the range of normal dam operations and is partially inundated only during controlled floods with magnitudes typically between 40,000 and 45,000 $\mathrm{ft}^{3} / \mathrm{s}$ (fig. 2). Normal MLFF dam operations typically involve release volumes that are higher in June, July, and August. During summer months, most available campsite area is in the high stage-elevation zone. We also reported "total" campsite area as the sum of the low and high stage-elevation zones. This sum includes all the campsite area consistently measured at all of the study sites.

Complete data sets for each study site are given in appendix A. The appendix contains, for each site, a site location map, a table of the campsite area data, time series plots for each stage elevation zone, maps of each survey, and photographs of the study site at the beginning and end of the study period, where available.

Time-series plots of the campsite area surveys show the changes to campsite area over time. A summary of the campsite area data in all three stage elevation zones (total, high, and low) is presented for all sites (fig. 4, table 3), sites in Marble and Grand Canyons (fig. 5, tables 4 and 5) to show longitudinal changes with distance away from GCD, and within critical and non-critical recreational segments (fig. 6, tables 6 and 7). Data were summarized by computing the mean and standard error of the mean for the campsite area measured within each stage elevation zone for each survey. The significance of the time series trends were evaluated by linear regression modeling (table 8). 
Table 3. Mean campsite area for all sites in low, high, and total stage elevation zones along the Colorado River, Grand Canyon National Park, Arizona, 1998-2012.

\begin{tabular}{|c|c|c|c|c|c|c|c|}
\hline \multirow[b]{2}{*}{ Survey date } & \multicolumn{2}{|c|}{ Low $^{1}$} & \multicolumn{2}{|c|}{ High $^{2}$} & \multicolumn{2}{|c|}{ Total $^{3}$} & \multirow[b]{2}{*}{$\mathrm{n}^{5}$} \\
\hline & Mean & s.e $e^{4}$ & Mean & s.e. ${ }^{4}$ & Mean & s.e. ${ }^{4}$ & \\
\hline October 1998 & 185 & 45 & 487 & 70 & 623 & 75 & 30 \\
\hline October 1999 & 105 & 31 & 458 & 61 & 537 & 65 & 31 \\
\hline October 2000 & 327 & 69 & 414 & 54 & 741 & 90 & 30 \\
\hline October 2001 & 222 & 69 & 353 & 54 & 574 & 86 & 30 \\
\hline October 2002 & 162 & 35 & 272 & 38 & 434 & 48 & 37 \\
\hline May 2003 & 254 & 47 & 229 & 31 & 483 & 57 & 37 \\
\hline October 2003 & 248 & 47 & 231 & 33 & 479 & 54 & 37 \\
\hline May 2005 & 301 & 63 & 302 & 40 & 593 & 79 & 37 \\
\hline October 2006 & 120 & 28 & 218 & 30 & 337 & 44 & 37 \\
\hline October 2007 & 119 & 23 & 164 & 25 & 282 & 33 & 37 \\
\hline February 2008 & 121 & 26 & 180 & 27 & 301 & 42 & 37 \\
\hline April 2008 & 212 & 61 & 398 & 52 & 610 & 100 & 37 \\
\hline October 2008 & 123 & 30 & 265 & 35 & 388 & 45 & 37 \\
\hline October 2009 & 82 & 20 & 225 & 29 & 307 & 36 & 37 \\
\hline October 2011 & 215 & 44 & 168 & 24 & 383 & 50 & 37 \\
\hline October 2012 & 211 & 42 & 160 & 23 & 371 & 49 & 37 \\
\hline
\end{tabular}

${ }^{1}$ Low $=$ campsite area measured between the 15,000 to $25,000 \mathrm{ft}^{3} / \mathrm{s}$ stage elevation zone.

${ }^{2} \mathrm{High}=$ campsite area measured above the $25,000 \mathrm{ft}^{3} / \mathrm{s}$ stage elevation zone.

${ }^{3}$ Total $=$ all campsite area measured above $15,000 \mathrm{ft}^{3} / \mathrm{s}$ stage elevation zone.

${ }^{4}$ s.e. $=$ standard error of the mean.

${ }^{5} \mathrm{n}=$ number of sites. 
Table 4. Mean campsite area for sites in low, high, and total stage elevation zones in Marble Canyon along the Colorado River, Arizona, 1998-2012.

\begin{tabular}{|c|c|c|c|c|c|c|c|}
\hline \multirow[b]{2}{*}{ Survey date } & \multicolumn{2}{|c|}{ Low $^{1}$} & \multicolumn{2}{|c|}{ High $^{2}$} & \multicolumn{2}{|c|}{ Total $^{3}$} & \multirow[b]{2}{*}{$n^{5}$} \\
\hline & Mean & s.e. ${ }^{4}$ & Mean & s.e. ${ }^{4}$ & Mean & s.e. ${ }^{4}$ & \\
\hline October 1998 & 221 & 83 & 549 & 105 & 637 & 114 & 11 \\
\hline October 1999 & 96 & 45 & 621 & 81 & 651 & 81 & 12 \\
\hline October 2000 & 365 & 143 & 502 & 78 & 867 & 165 & 10 \\
\hline October 2001 & 335 & 160 & 390 & 66 & 725 & 161 & 11 \\
\hline October 2002 & 144 & 48 & 304 & 55 & 448 & 56 & 16 \\
\hline May 2003 & 230 & 60 & 258 & 48 & 488 & 78 & 16 \\
\hline October 2003 & 203 & 61 & 284 & 59 & 487 & 71 & 16 \\
\hline May 2005 & 305 & 61 & 363 & 55 & 646 & 80 & 16 \\
\hline October 2006 & 118 & 40 & 263 & 37 & 381 & 58 & 16 \\
\hline October 2007 & 119 & 36 & 215 & 42 & 335 & 54 & 16 \\
\hline February 2008 & 133 & 47 & 236 & 45 & 369 & 75 & 16 \\
\hline April 2008 & 357 & 126 & 472 & 91 & 830 & 198 & 16 \\
\hline October 2008 & 171 & 52 & 315 & 52 & 485 & 64 & 16 \\
\hline October 2009 & 100 & 31 & 241 & 39 & 341 & 44 & 16 \\
\hline October 2011 & 214 & 75 & 203 & 39 & 418 & 71 & 16 \\
\hline October 2012 & 248 & 60 & 196 & 43 & 444 & 73 & 16 \\
\hline
\end{tabular}

${ }^{1}$ Low $=$ campsite area measured between the 15,000 to $25,000 \mathrm{ft}^{3} / \mathrm{s}$ stage elevation zone.

${ }^{2} \mathrm{High}=$ campsite area measured above the $25,000 \mathrm{ft}^{3} / \mathrm{s}$ stage elevation zone.

${ }^{3}$ Total $=$ all campsite area measured above $15,000 \mathrm{ft}^{3} / \mathrm{s}$ stage elevation zone.

${ }^{4}$ s.e. $=$ standard error of the mean.

${ }^{5} \mathrm{n}=$ number of sites. 
Table 5. Mean campsite area for sites in low, high, and total stage elevation zones in Grand Canyon along the Colorado River, Grand Canyon National Park, Arizona, 1998-2012.

\begin{tabular}{|c|c|c|c|c|c|c|c|}
\hline \multirow[b]{2}{*}{ Survey date } & \multicolumn{2}{|c|}{ Low $^{1}$} & \multicolumn{2}{|c|}{ High $^{2}$} & \multicolumn{2}{|c|}{ Total $^{3}$} & \multirow[b]{2}{*}{$\mathrm{n}^{5}$} \\
\hline & Mean & s.e. ${ }^{4}$ & Mean & s.e. ${ }^{4}$ & Mean & s.e. ${ }^{4}$ & \\
\hline October 1998 & 164 & 53 & 451 & 94 & 615 & 100 & 19 \\
\hline October 1999 & 111 & 43 & 354 & 78 & 466 & 91 & 19 \\
\hline October 2000 & 308 & 77 & 370 & 70 & 677 & 107 & 20 \\
\hline October 2001 & 156 & 55 & 331 & 77 & 487 & 96 & 19 \\
\hline October 2002 & 176 & 50 & 247 & 53 & 424 & 75 & 21 \\
\hline May 2003 & 272 & 70 & 207 & 41 & 479 & 82 & 21 \\
\hline October 2003 & 283 & 69 & 190 & 36 & 473 & 80 & 21 \\
\hline May 2005 & 298 & 102 & 255 & 56 & 553 & 126 & 21 \\
\hline October 2006 & 121 & 41 & 183 & 43 & 304 & 65 & 21 \\
\hline October 2007 & 118 & 31 & 125 & 28 & 243 & 41 & 21 \\
\hline February 2008 & 112 & 30 & 138 & 31 & 250 & 46 & 21 \\
\hline April 2008 & 101 & 36 & 342 & 59 & 443 & 77 & 21 \\
\hline October 2008 & 87 & 34 & 227 & 47 & 314 & 58 & 21 \\
\hline October 2009 & 69 & 26 & 212 & 43 & 281 & 53 & 21 \\
\hline October 2011 & 216 & 55 & 141 & 30 & 357 & 70 & 21 \\
\hline October 2012 & 182 & 59 & 133 & 25 & 315 & 66 & 21 \\
\hline
\end{tabular}

${ }^{1}$ Low $=$ campsite area measured between the 15,000 to $25,000 \mathrm{ft}^{3} / \mathrm{s}$ stage elevation zone.

${ }^{2} \mathrm{High}=$ campsite area measured above the $25,000 \mathrm{ft}^{3} / \mathrm{s}$ stage elevation zone.

${ }^{3}$ Total $=$ all campsite area measured above $15,000 \mathrm{ft}^{3} / \mathrm{s}$ stage elevation zone.

${ }^{4}$ s.e. $=$ standard error of the mean.

${ }^{5} \mathrm{n}=$ number of sites. 
Table 6. Mean campsite area for sites in critical reaches in low, high, and total stage elevation zones along the Colorado River, Grand Canyon National Park, Arizona, 1998-2012.

\begin{tabular}{|c|c|c|c|c|c|c|c|}
\hline \multirow[b]{2}{*}{ Survey date } & \multicolumn{2}{|c|}{ Low $^{1}$} & \multicolumn{2}{|c|}{ High $^{2}$} & \multicolumn{2}{|c|}{ Total $^{3}$} & \multirow[b]{2}{*}{$\mathrm{n}^{5}$} \\
\hline & Mean & s.e. ${ }^{4}$ & Mean & s.e. ${ }^{4}$ & Mean & s.e. ${ }^{4}$ & \\
\hline October 1998 & 185 & 77 & 388 & 83 & 573 & 89 & 13 \\
\hline October 1999 & 127 & 50 & 360 & 82 & 487 & 80 & 13 \\
\hline October 2000 & 234 & 60 & 364 & 75 & 598 & 96 & 14 \\
\hline October 2001 & 128 & 41 & 304 & 79 & 432 & 76 & 13 \\
\hline October 2002 & 173 & 49 & 228 & 56 & 401 & 63 & 16 \\
\hline May 2003 & 244 & 77 & 197 & 44 & 442 & 86 & 16 \\
\hline October 2003 & 222 & 78 & 193 & 42 & 415 & 79 & 16 \\
\hline May 2005 & 292 & 112 & 283 & 60 & 574 & 129 & 16 \\
\hline October 2006 & 100 & 45 & 232 & 53 & 332 & 70 & 16 \\
\hline October 2007 & 93 & 29 & 179 & 39 & 272 & 41 & 16 \\
\hline February 2008 & 107 & 29 & 171 & 36 & 278 & 45 & 16 \\
\hline April 2008 & 187 & 61 & 353 & 68 & 541 & 91 & 16 \\
\hline October 2008 & 164 & 61 & 265 & 50 & 429 & 68 & 16 \\
\hline October 2009 & 102 & 38 & 223 & 42 & 325 & 52 & 16 \\
\hline October 2011 & 225 & 83 & 176 & 41 & 401 & 84 & 16 \\
\hline October 2012 & 242 & 82 & 169 & 34 & 411 & 84 & 16 \\
\hline
\end{tabular}

${ }^{1}$ Low $=$ campsite area measured between the 15,000 to $25,000 \mathrm{ft}^{3} / \mathrm{s}$ stage elevation zone.

${ }^{2} \mathrm{High}=$ campsite area measured above the $25,000 \mathrm{ft}^{3} / \mathrm{s}$ stage elevation zone.

${ }^{3}$ Total $=$ all campsite area measured above $15,000 \mathrm{ft}^{3} / \mathrm{s}$ stage elevation zone.

${ }^{4}$ s.e. $=$ standard error of the mean.

${ }^{5} \mathrm{n}=$ number of sites. 
Table 7. Mean campsite area for sites in non-critical reaches in low, high, and total stage elevation zones along the Colorado River, Grand Canyon National Park, Arizona, 1998-2012.

\begin{tabular}{|c|c|c|c|c|c|c|c|}
\hline \multirow[b]{2}{*}{ Survey date } & \multicolumn{2}{|c|}{ Low $^{1}$} & \multicolumn{2}{|c|}{ High $^{2}$} & \multicolumn{2}{|c|}{ Total $^{3}$} & \multirow[b]{2}{*}{$n^{5}$} \\
\hline & Mean & s.e. ${ }^{4}$ & Mean & s.e. ${ }^{4}$ & Mean & s.e. ${ }^{4}$ & \\
\hline October 1998 & 185 & 55 & 563 & 105 & 661 & 115 & 17 \\
\hline October 1999 & 90 & 40 & 528 & 85 & 573 & 97 & 18 \\
\hline October 2000 & 408 & 117 & 457 & 77 & 865 & 142 & 16 \\
\hline October 2001 & 293 & 115 & 390 & 75 & 683 & 136 & 17 \\
\hline October 2002 & 154 & 50 & 305 & 52 & 459 & 71 & 21 \\
\hline May 2003 & 262 & 60 & 253 & 43 & 515 & 77 & 21 \\
\hline October 2003 & 268 & 60 & 260 & 48 & 528 & 74 & 21 \\
\hline May 2005 & 308 & 74 & 317 & 56 & 608 & 102 & 21 \\
\hline October 2006 & 135 & 37 & 206 & 34 & 341 & 59 & 21 \\
\hline October 2007 & 138 & 35 & 152 & 33 & 290 & 51 & 21 \\
\hline February 2008 & 132 & 41 & 187 & 40 & 319 & 67 & 21 \\
\hline April 2008 & 231 & 98 & 432 & 76 & 663 & 163 & 21 \\
\hline October 2008 & 92 & 24 & 265 & 50 & 357 & 60 & 21 \\
\hline October 2009 & 67 & 19 & 226 & 41 & 293 & 49 & 21 \\
\hline October 2011 & 208 & 47 & 162 & 30 & 369 & 61 & 21 \\
\hline October 2012 & 187 & 42 & 153 & 33 & 340 & 60 & 21 \\
\hline
\end{tabular}

${ }^{1}$ Low $=$ campsite area measured between the 15,000 to $25,000 \mathrm{ft}^{3} / \mathrm{s}$ stage elevation zone.

${ }^{2} \mathrm{High}=$ campsite area measured above the $25,000 \mathrm{ft}^{3} / \mathrm{s}$ stage elevation zone.

${ }^{3}$ Total $=$ all campsite area measured above $15,000 \mathrm{ft}^{3} / \mathrm{s}$ stage elevation zone.

${ }^{4}$ s.e. $=$ standard error of the mean.

${ }^{5} \mathrm{n}=$ number of sites. 
Table 8. Results of linear regression of mean campsite-area time series presented in tables 2 through 6 , Grand Canyon National Park, Arizona, 1998-2012.

\begin{tabular}{ccccc}
\hline Sites & Stage zone & $\mathbf{F}^{1}$ & $\mathbf{P}^{2}$ & $\left.\mathbf{( R}^{2}\right)^{3}$ \\
\hline all sites & low & 0.93 & 0.351 & 0.06 \\
all sites & high & 19.16 & 0.001 & 0.58 \\
all sites & total & 11.86 & 0.004 & 0.46 \\
Marble Canyon & low & 0.33 & 0.574 & 0.02 \\
Marble Canyon & high & 17.50 & 0.001 & 0.56 \\
Marble Canyon & total & 5.78 & 0.031 & 0.29 \\
Grand Canyon & low & 1.40 & 0.256 & 0.09 \\
Grand Canyon & high & 19.11 & 0.001 & 0.58 \\
Grand Canyon & total & 19.00 & 0.001 & 0.58 \\
critical & low & 0.01 & 0.920 & 0.00 \\
critical & high & 10.92 & 0.005 & 0.44 \\
critical & total & 5.15 & 0.040 & 0.27 \\
noncritical & low & 1.82 & 0.198 & 0.12 \\
noncritical & high & 24.06 & 0.000 & 0.63 \\
noncritical & total & 14.99 & 0.002 & 0.52 \\
\hline
\end{tabular}

${ }^{1}$ F-ratio from single factor ANOVA with degrees of freedom $=1,14$.

${ }^{2} \mathrm{P}$ is the significance of the F-ratio. Significance at the 95 percent level $=0.05$.

${ }^{3} R^{2}$ represents the percentage of variation explained by the fitted line, or "goodness of fit" of the line. 

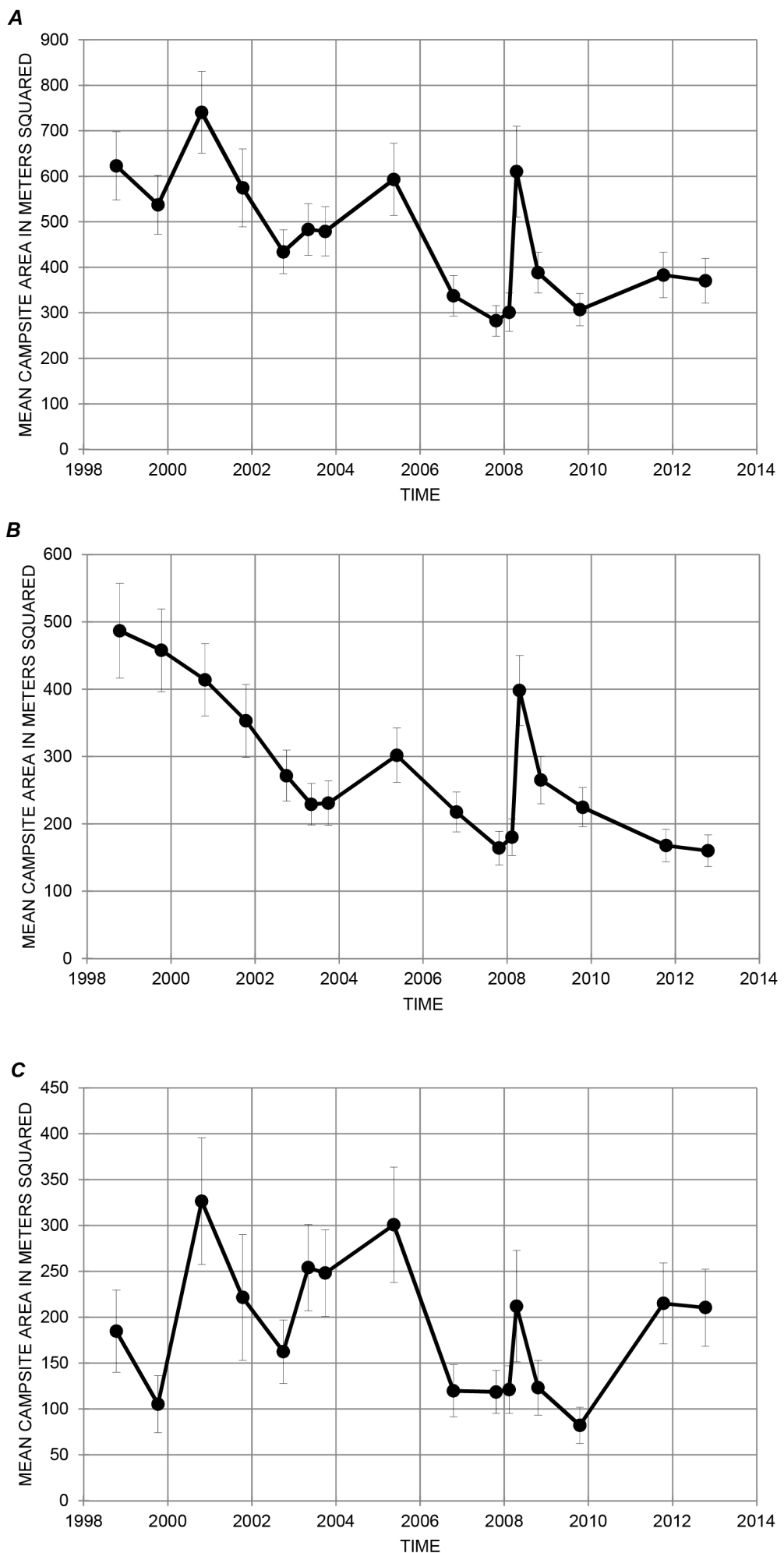

Figure 4. Time series plots showing mean campsite area for all sites along the Colorado River, Grand Canyon National Park, Arizona. Standard error of the mean shown by error bars $(A)$ Mean campsite area in total (greater than $15,000 \mathrm{ft}^{3} / \mathrm{s}$ ) stage-elevation zone; (B) mean campsite area in high (greater than $25,000 \mathrm{ft} 3 / \mathrm{s}$ ) stage-elevation zone; $(C)$ mean campsite area of low $(15,000-25,000 \mathrm{ft} / 3 / \mathrm{s})$ stage-elevation zone. Refer to table 2 for data. 

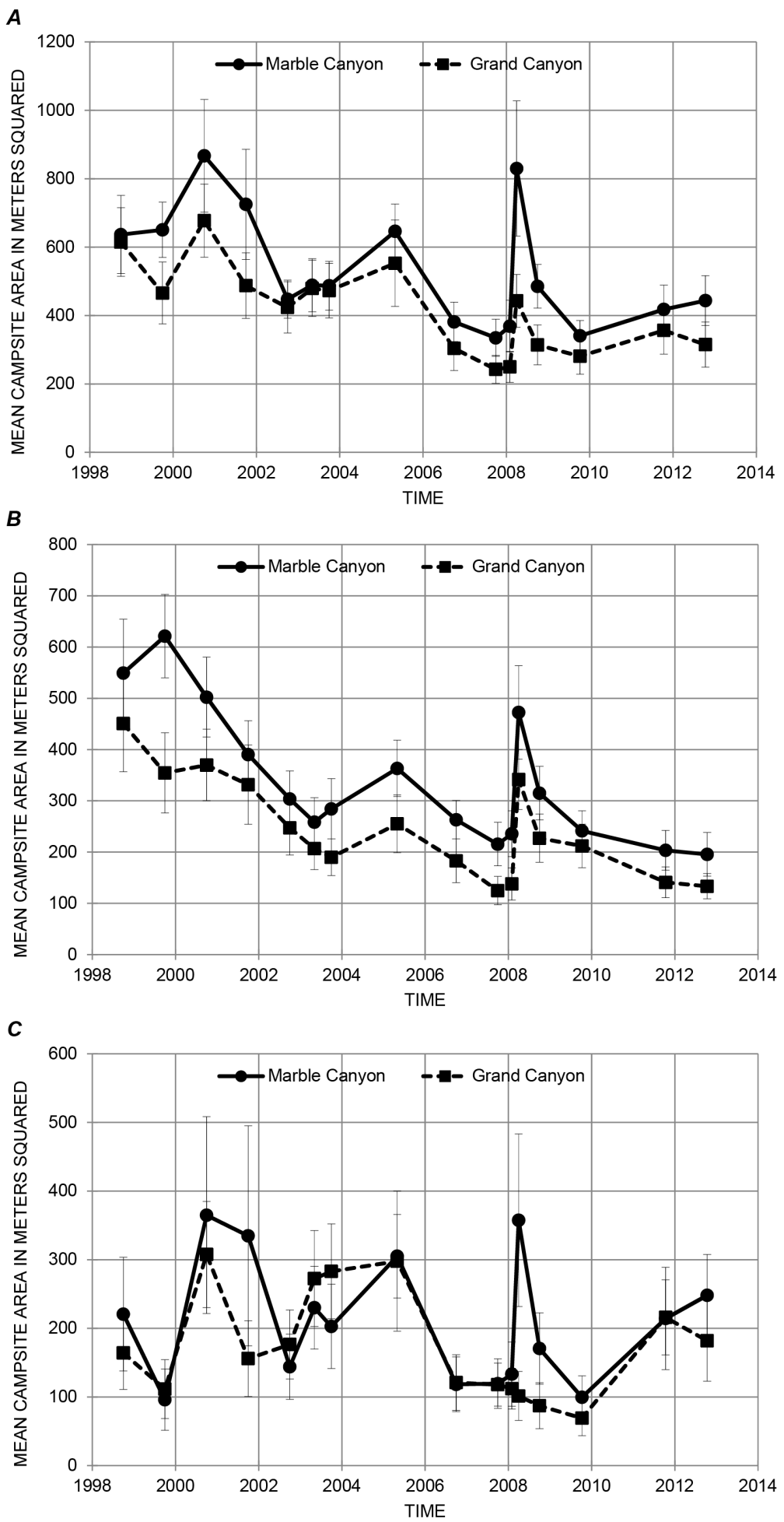

Figure 5. Time series plots showing mean campsite area for sites in Marble and Grand Canyons along the Colorado River, Grand Canyon National Park, Arizona. Standard error of the mean shown by error bars. $(A)$ Mean campsite area in total (greater than $15,000 \mathrm{ft}^{3} / \mathrm{s}$ ) stage-elevation zone; $(B)$ mean campsite area in high (greater than $25,000 \mathrm{ft} 3 / \mathrm{s})$ stage-elevation zone; $(C)$ mean campsite area of low $(15,000-25,000 \mathrm{ft} / 3 / \mathrm{s})$ stage-elevation zone. Refer to tables 3 and 4 for data. 

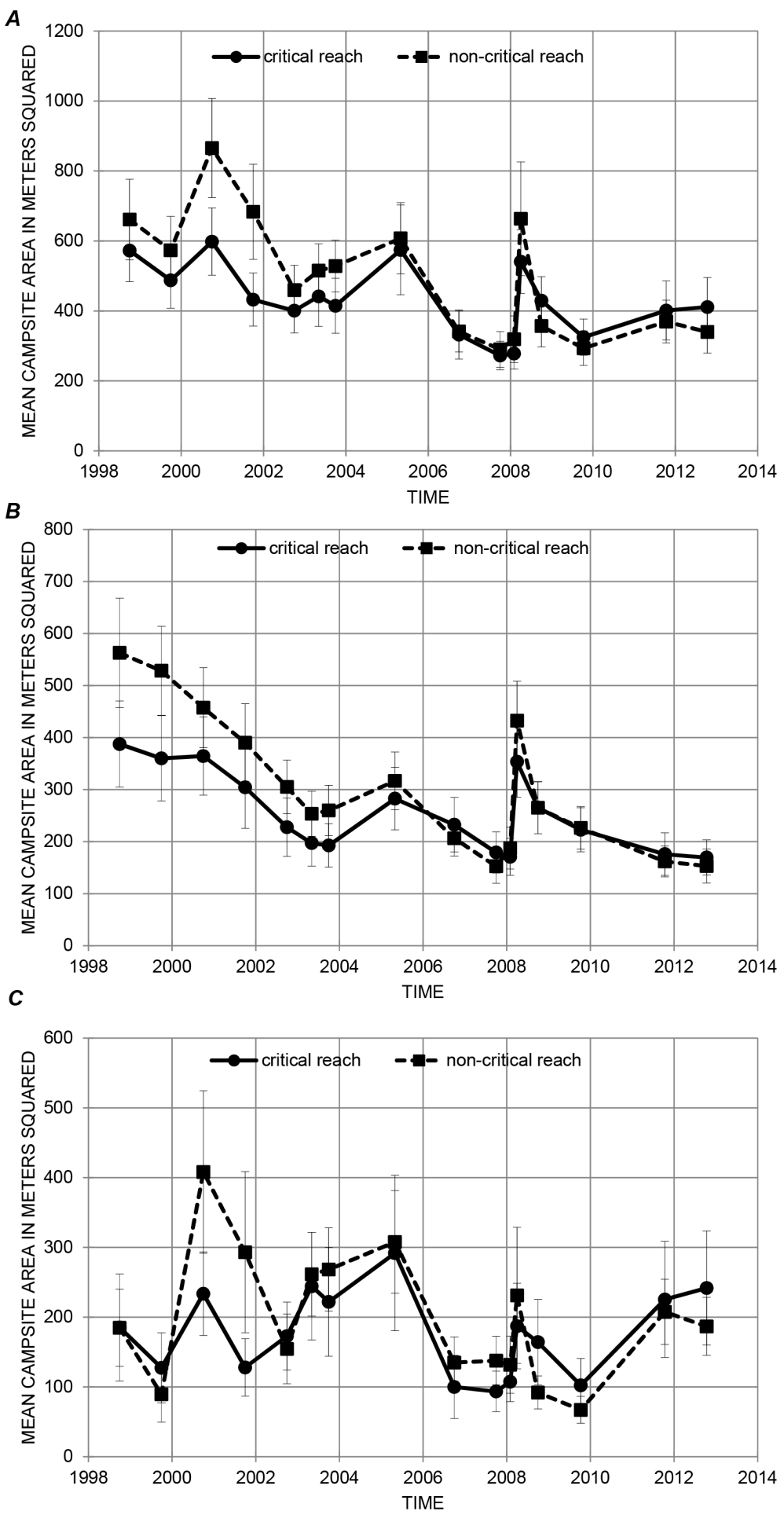

Figure 6. Time series plots showing mean campsite area for sites in critical and non-critical recreational segments along the Colorado River, Grand Canyon National Park, Arizona. Standard error of the mean shown by error bars. (A) Mean campsite area in total (greater than 15,000 ft3/s) stage-elevation zone; $(B)$ mean campsite area in high (greater than $25,000 \mathrm{ft} 3 / \mathrm{s}$ ) stage-elevation zone; $(C)$ mean campsite area of low $(15,000-25,000 \mathrm{ft} 3 / \mathrm{s})$ stageelevation zone. Refer to tables 5 and 6 for data. 


\section{Results and Conclusions}

Campsite area decreased over the course of the study period, but varied strongly by elevation zone and between surveys (figs. 4, 5, and 6). From 1998 to 2012, the mean total campsite area decreased by an average of 36 percent and decreased at 29 of the 37 study sites. Regression modeling shows that the decreasing trend in the total amount of campsite area (figs. 4A, 5A, and 6A) is significant ( $\mathrm{p}<0.05$; table 8). Campsite area within the high stage-elevation zone shows a significant decreasing trend $(\mathrm{p}<0.05$; table 8 ) for all categories of sites (figs. $4 B, 5 B$, and $6 B$ ), whereas there was no significant longterm trend in low stage-elevation campsite area (figs. $4 C, 5 C$, and $6 C$ ). Campsite area decreased at all 37 study sites in the high stage-elevation zone by an average of 61 percent. In the low stage-elevation zone, 21 sites increased in campsite area, 12 sites decreased in area, and 4 sites showed no change.

The effects of dam operations on campsite area are highlighted by examining changes between surveys. In the high stage-elevation zone, campsite area increased for all categories (all sites, Marble Canyon, Grand Canyon, critical and non-critical) after the controlled floods in November 2004 and March 2008 (fig. 2). Increases in high stage-elevation campsite area result from sandbar deposition during controlled floods (Grams and others, 2010; Hazel and others, 2010), where deposition builds larger bars, fills gullies, and buries or removes vegetation. In contrast, high stage-elevation campsite area decreased in the intervals between high flows when normal Record of Decision (ROD) flows did not inundate the high-elevation zone. The two powerplant capacity (about $31,000 \mathrm{ft}^{3} / \mathrm{s}$ ) controlled floods released during the 2000 LSSF experiment only partially inundated the high stage-elevation zone but did not increase campsite area in this zone. The loss of campsite area during these intervals is likely due to a combination of changes in sandbar slope and vegetation growth.

In the low stage-elevation zone, campsite area increases occurred after higher volume flows within powerplant capacity as well as the two controlled floods greater than powerplant capacity. Low stage-elevation campsite area increased after the two powerplant capacity controlled floods during the 2000 LSSF experiment, the high-fluctuating flows from January to March 2003, the 2004 and 2008 controlled floods, and the summer 2011 high-steady flows. Campsite area increased during these intervals because flows partially or completely inundated the low stage-elevation zone, deposited sediment (if sediment concentrations were high enough), and inhibited vegetation growth.

The campsite area surveys show a long term loss in campsite area. We conclude that dam operations have not met the management objectives of the Glen Canyon Adaptive Management program to increase the size of camping beaches in critical and non-critical reaches of the Colorado River between Glen Canyon Dam and Lake Mead. However, a more thorough investigation is needed to better quantify the mechanisms that cause campsite area change. We are currently conducting an analysis that aims to correlate changes in campsite area with changes in topography and vegetation to provide a more complete analysis of changes to campsite area along the Colorado River in Grand Canyon.

\section{Acknowledgments}

The authors wish to thank the many people who helped with data collection. Helen Fairley, Carol Fritzinger, Tom Gushue, Keith Kohl, Rob Ross, Aaron Borling, Jeff Behan, Greg Sponenburgh, Erik Kellerup, Laura Kennedy, Karen Koestner, Ryan Seumptewa, and Meagan Polino were instrumental in collecting field data. Funding for this work was provided through the Glen Canyon Dam Adaptive Management program of the Bureau of Reclamation. 


\section{References Cited}

Belknap, B., 2001, Grand Canyon river guide: Evergreen, Colo., Westwater Books, 96 p.

Beus, S.B., Avery, C.C., Stevens, L., Cluer, B., Kaplinski, M., Anderson, P., Bennett, J., Brod, C., Hazel, J., Gonzales, M., Mayes, H., Protiva, F., and Courson, J., 1992, The influence of variable discharge regimes on Colorado River sand bars below Glen Canyon Dam: Bureau of Reclamation, Final report to Glen Canyon Environmental Studies, 61 p.

Beus, S.S., Carothers, S.W., and Avery, C.C., 1985, Topographic changes in fluvial terrace deposits used as campsite beaches along the Colorado River in Grand Canyon: Journal of the Arizona-Nevada Academy of Science, v. 20, p. 111-120.

Bureau of Reclamation, 2001, Glen Canyon Dam Adaptive Management Program Strategic Plan, Bureau of Reclamation, Upper Colorado Region, Resource Management, Adaptive Management, accessed July 16, 2014, at http://www.usbr.gov/uc/rm/amp/strategic_plan.html.

Draut, A.E., and Rubin, D.M., 2007, The role of Aeolian sediment in the preservation of archeological sites in the Colorado River corridor, Grand Canyon, Arizona-Final report on research activities, 2003-2006: U.S. Geological Survey Open-File Report 2007-1001, 141 p.

Grams, P.E., Schmidt, J.C., and Andersen, M.E., 2010, 2008 high-flow experiment at Glen Canyon Dam-Morphologic response of eddy-deposited sandbars and associated aquatic backwater habitats along the Colorado River in Grand Canyon National Park: U.S. Geological Survey Open-File Report 2010-1032, 73 p.

Hazel, J.E., Jr., Grams, P.E., Schmidt, J.C., and Kaplinski, M., 2010, Sandbar response in Marble and Grand Canyons, Arizona, following the 2008 high-flow experiment on the Colorado River: U.S. Geological Survey Scientific Investigations Report 2010-5015, 52 p.

Hazel, J.E., Jr., Kaplinski, M., Parnell, R., Manone, M., and Dale, A., 1999, Topographic and bathymetric changes at thirty-three long-term study sites, in Webb, R.H., Schmidt, J.C., Marzolf, G.R., and Valdez, R.A., eds., The controlled flood in Grand Canyon: American Geophysical Union Geophysical Monograph 110, p. 161-183.

Hazel, J.E., Jr., Kaplinski, M., Parnell, R.A., Kohl, K., and Schmidt, J.C., 2008, Monitoring fine-grained sediment in the Colorado River Ecosystem, Arizona-Control network and conventional survey techniques: U.S. Geological Survey Open-File Report 2008-1276, 240 p.

Hazel, J.E., Jr., Kaplinski, M., Parnell, R.A., Kohl, K., and Topping, D.J., 2006, Stage-discharge relations for the Colorado River ecosystem in Glen, Marble, and Grand Canyons, Arizona: U.S. Geological Survey Open-File Report 2006-1243, 7 p.

Howard, A.D., and Dolan, R., 1981, Geomorphology of the Colorado River in Grand Canyon: Journal of Geology, v. 89, p. 269-297.

Kaplinski, M., Behan, J., Hazel, J., Parnell, R.A., and Fairley, H.C., 2005, Recreational values and campsites in the Colorado River ecosystem, chap. 12 of Gloss, S., Lovich, J.E., and Melis, T., eds., The state of the Colorado River ecosystem in Grand Canyon: U.S. Geological Survey Circular 1282, p. 193-205.

Kaplinski, M., Hazel, J.E., Jr., and Beus, S.S., 1995, Monitoring the effects of interim flows from Glen Canyon Dam on sand bars in the Colorado River Corridor, Grand Canyon National Park, Arizona: Flagstaff, Northern Arizona University, Final report to the National Park Service, cooperative agreement no. CA8022-8-0002, 62 p. 
Kaplinski, M., Hazel, J.E., Jr., and Parnell, R., 2010, Colorado River Campsite Monitoring, 19982006, Grand Canyon National Park, Arizona, in Melis, T.S., Hamill, J.F., Coggins, L.C., Jr., Grams, P.E., Kennedy, T.A., Kubly, D.M., and Ralston, B.E., eds., Proceedings of the Colorado River Basin Science and Resource Management Symposium, November 18-20, 2009: U.S. Geological Survey Scientific Investigations Report 2010-5135, 372 p.

Kearsley, M.J.C., and Ayers, T.J., 1996, The effects of interim flows from Glen Canyon Dam on riparian vegetation in the Colorado River corridor, Grand Canyon National Park, Arizona: Flagstaff, Northern Arizona University, Final report submitted to the Grand Canyon Science Center, Grand Canyon National Park, 40 p. plus appendices.

Kearsley, L.H., Schmidt, J.C., and Warren, K.D., 1994, Effects of Glen Canyon Dam on Colorado River sand deposits used as campsites in Grand Canyon National Park, USA: Regulated Rivers, v. 9, p. 138-149.

Kearsley, L.H., and Warren, K.W., 1993, River campsites in Grand Canyon National Park-Inventory and effects of discharge on campsite size and availability: National Park Service Division of Resource Management, Grand Canyon National Park, 65 p.

Melis, T.S., Webb, R.H., Griffiths, P.G., and Wise, T.W., 2004, Magnitude and frequency data for historic debris flows in Grand Canyon National Park and vicinity, Arizona: U.S. Geological Survey Investigations Report 94-4214, 204 p. plus appendices.

McCullagh, M.J., 1988, Terrain and surface modeling systems-Theory and practice: Photogrammetric Record, v. 12, no. 72, p. 747-779.

National Park Service, 2006, Colorado River Management Plan: U.S. Department of the Interior National Park Service, Grand Canyon National Park, 35 p.

National Research Council, 1999, Downstream-Adaptive management of Glen Canyon Dam and the Colorado River ecosystem: Washington, D.C., National Academy Press, 242 p.

Phillips, B.G., Johnson, R.A., Phillips, A.M., III, and Brian, N.J., 1986, Monitoring the effects of recreational use on Colorado River beaches in Grand Canyon National Park: Flagstaff, Ariz., Museum of Northern Arizona Press, Museum of Northern Arizona Bulletin 55, 105 p. plus appendices.

Rubin D.M., Topping, D., Schmidt, J.C., Hazel, J.E., Kaplinski, M., and Melis, T., 2002, Recent sediment studies refute Glen Canyon Dam hypothesis: EOS, Transactions of the American Geophysical Union, v. 83, no. 25, p. 273, 277-278.

Schmidt, J.C., and Graf, J.B., 1990, Aggradation and degradation of alluvial sand deposits, 1965 to 1986, Colorado River, Grand Canyon National Park, Arizona: U.S. Geological Survey Professional Paper 1493, 74 p.

Schmidt, J.C., and Grams, P.E., 2011, The high flows-Physical science results, in Melis, T.S., ed., 2011, Effects of three high-flow experiments on the Colorado River ecosystem downstream from Glen Canyon Dam, Arizona: U.S. Geological Survey Circular 1366, chap. 3, 147 p.

Schmidt, J.C., Topping, D.J., Grams, P.E., and Hazel, J.E., Jr., 2004, System-wide changes in the distribution of fine sediment in the Colorado River corridor between Glen Canyon Dam and Bright Angel Creek, Arizona, final report: Logan, Utah State University, submitted to U.S. Geological Survey, Grand Canyon Monitoring and Research Center, cooperative agreement no. 1425-98-FC-4022640, $107 \mathrm{p}$.

Stevens, L., 1990, The Colorado River through Grand Canyon: Flagstaff, Ariz., Red Lake Books. Stewart, W., Larkin, K., Orland, B., Anderson, D., Manning, R., Cole, D., Taylor, J., and Tomar, N., 2000, Preferences of recreation user groups of the Colorado River in Grand Canyon: Final report to the Grand Canyon Monitoring and Research Center, cooperative agreement no. 98-FG-40-0190. 
Topping, D.J., Rubin, D.M., and Vierra, L.E.J., 2000, Colorado River sediment transport 1—Natural sediment supply limitation and the influence of Glen Canyon Dam: Water Resources Research, v. 36, no. 2, p. 515-542.

Turner, R.M., and Karpiscak, M.M., 1980, Recent vegetation changes along the Colorado River between Glen Canyon Dam and Lake Mead, Arizona: U.S. Geological Survey Professional Paper $1132,125 \mathrm{p}$.

U.S. Department of the Interior, 1995, Operation of Glen Canyon Dam-Final environmental impact statement: Salt Lake City, Utah, Bureau of Reclamation, Upper Colorado Region, 337 p. plus appendices.

U.S. Department of the Interior, 1996, Record of decision, operation of Glen Canyon Dam-Final Environmental Impact Statement: Bureau of Reclamation, $15 \mathrm{p}$.

U.S. Department of Interior, 2007, Record of decision, interim guidelines of the operation of Lake Powell and Lake Mead, environmental impact statement: Office of the Secretary of Interior, Bureau of Reclamation, $61 \mathrm{p}$.

U.S. Geological Survey, 2013, Grand Canyon Monitoring and Research Center, Colorado Mileage System [Spatial Database, GIS.BASE_GCMRC_TenthMile], 1st revised edition: U.S. Geological Survey database, accessed September 18, 2013, at http://www.gcmrc.gov/gis/silveratlas1.aspx. Webb, R.H., Melis, T.S., and Valdez, R.A., 2002, Observations of environmental change in grand Canyon, Arizona: U.S. Geological Survey Water Resources Investigations Report 02-4080. 33 p. Wright, S.A., Melis, T.S., Topping, D.J., and Rubin, D.M., 2005, Influence of Glen Canyon Dam operations on downstream sand resources of the Colorado River in Grand Canyon, in Gloss, S.P., Lovich, J.E., and Melis, T.S., eds., The state of the Colorado River ecosystem in Grand Canyon: U.S. Geological Survey Circular 1282, p. 17-31. 


\section{Appendix A. Campsite Area Data for Each Study Site}

The appendix contains, for each site, a site location map, a table of the campsite area data, time series plots for each stage elevation zone, maps of each survey, and photographs of the study site at the beginning and end of the study period, where available.Appendix A in .PDF format can be downloaded from http://pubs.usgs.gov/ofr/2014/1161. 
Publishing support provided by the U.S. Geological Survey

Publishing Network, Tacoma Publishing Service Center

For more information concerning the research in this report, contact the SBSC staff, Southwest Biological Science Center

U.S. Geological Survey

2255 N. Gemini Drive

Flagstaff, AZ 86001

http://sbsc.wr.usgs.gov/ 


\section{हू}

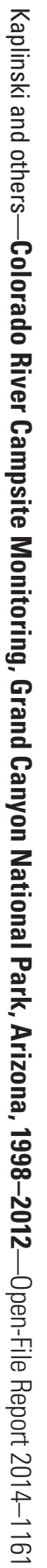

